\title{
HIGH LEVELS OF RELATEDNESS BETWEEN BROWN-HEADED COWBIRD (MOLOTHRUS ATER) NESTMATES IN A HEAVILY PARASITIZED HOST COMMUNITY
}

\author{
James W. Rivers, ${ }^{1,3}$ Sarah Young, ${ }^{2,4}$ Elena G. Gonzalez, ${ }^{2,5}$ Brent Horton, $^{2,6}$ Justin Lock, ${ }^{2}$ And \\ ROBERT C. FleisCheR ${ }^{2}$ \\ ${ }^{1}$ Department of Ecology, Evolution, and Marine Biology, University of California, Santa Barbara, California 93106, USA; and \\ ${ }^{2}$ Center for Conservation and Evolutionary Genetics, National Zoological Park, Smithsonian Institution, Washington, D.C. 20008, USA
}

\begin{abstract}
Multiple parasitism of host nests by generalist brood parasites reflects the decisions of laying females and may influence the development and behavior of parasitic young. We used microsatellite and mtDNA control-region haplotype data to examine the relatedness of Brown-headed Cowbird (Molothrus ater) offspring in multiply parasitized nests sampled from a heavily parasitized host community in northeastern Kansas. We also examined how host nest availability influenced the degree of multiple parasitism, and used community-wide parasitism data to explore whether female cowbirds were constrained in their laying decisions. Relatedness estimates for all suitable pairwise comparisons ( $n=94$ from 41 multiply parasitized nests) found that the mean likelihood than an individual cowbird in a multiply parasitized nest shared its nest with a full sibling was $40.4 \%$ (95\% confidence interval: $28.4-$ 52.4\%), indicating that many cowbird offspring were reared with full siblings. Extensive community-wide parasitism data revealed that most cowbird offspring shared the nest with $\geq 1$ other conspecific. Additionally, we found that the proportion of available host nests increased steeply at the start of the breeding season and remained high for most of the breeding season, but that the degree of multiple parasitism was unrelated to the number of new nests. We found evidence that laying decisions of female cowbirds were constrained, which suggests that heavy parasitism levels were due to a high degree of competition for host nests. This intense competition for host nests, in turn, results in cowbird offspring often competing with conspecifics in our population, including full siblings, for host parental care. Received 14 October 2011, accepted 13 July 2012.
\end{abstract}

Key words: Brown-headed Cowbird, generalist brood parasite, kinship, laying pattern, Molothrus ater, nestmate relatedness.

\section{Altos Grados de Parentesco entre Individuos de Molothrus ater Criados en el Mismo Nido en una Comunidad Hospedera Fuertemente Parasitada}

RESUMEN.-El parasitismo múltiple de los nidos de los hospederos por parte de parásitos de cría generalistas refleja las decisiones de las hembras y puede afectar el desarrollo y el comportamiento de las crías parásitas. Usamos datos de microsatélites y de la región control del ADNmt para examinar el parentesco de las crías de Molothrus ater en nidos parasitados múltiples veces en una comunidad hospedera fuertemente parasitada en el nororiente de Kansas. También examinamos cómo la disponibilidad de nidos de hospederos afecta el grado de parasitismo múltiple, y usamos los datos de parasitismo de toda la comunidad para explorar si las hembras de M. ater vieron restringidas sus decisiones de postura de huevos. Con los estimados de parentesco para todas las combinaciones posibles por pares ( $n=94$ en 41 nidos parasitados múltiples veces) encontramos que la probabilidad media de que un individuo de $M$. ater comparta un nido con un hermano en un nido parasitado múltiples veces es de 40.4\% (intervalo de confianza del 95\%: 28.4-52.4\%), lo que indica que muchas crías de $M$. ater comparten el nido con hermanos. Los datos de parasitismo de toda la comunidad revelaron que la mayoría de las crías de $M$. ater compartieron el nido con más de un individuo coespecífico. Además, encontramos que la proporción de nidos del hospedero disponibles se incrementó pronunciadamente al inicio de la temporada reproductiva y se mantuvo alta durante la mayor

${ }^{3}$ Present address: Department of Forest Ecosystems and Society, Oregon State University, Corvallis, Oregon 97331, USA.

E-mail: jim.rivers@oregonstate.edu

${ }^{4}$ Present address: Department of Biological Sciences, University of Pittsburgh, 4249 Fifth Avenue, Pittsburgh, Pennsylvania 15260, USA.

${ }^{5}$ Present address: Departamento de Biodiversidad y Biología Evolutiva, Museo Nacional de Ciencias Naturales, CSIC, José Gutiérrez Abascal 2, 28006 Madrid, Spain.

${ }^{6}$ Present address: Department of Psychology, Emory University, 1510 Clifton Road NE, Atlanta, Georgia 30322, USA.

The Auk, Vol. 129, Number 4, pages 623-631. ISSN 0004-8038, electronic ISSN 1938-4254. @ 2012 by The American Ornithologists' Union. All rights reserved. Please direct all requests for permission to photocopy or reproduce article content through the University of California Press's Rights and Permissions website, http://www.ucpressjournals com/reprintInfo.asp. DOI: 10.1525/auk.2012.11236 
parte de la misma, pero que el grado de parasitismo múltiple no estuvo relacionado con el número de nidos nuevos. Encontramos evidencia de que las decisiones de postura de huevos de las hembras de $M$. ater estuvieron restringidas, lo que sugiere que los niveles altos de parasitismo se debieron a un alto grado de competencia por los nidos de los hospederos. A su vez, la intensa competencia por los nidos de los hospederos en esta población conduce a que las crías de $M$. ater compitan frecuentemente con individuos coespecíficos, incluyendo a sus hermanos, por el cuidado parental de sus hospederos.

OBLIGATE BROOD PARASITISM is an uncommon reproductive strategy among birds, occurring in $~ 100$ avian species in seven evolutionarily independent lineages (Rothstein 1990, Davies 2000). Compared to specialized brood parasites that use only one or several hosts to raise their young, generalist brood parasites may parasitize $>100$ host species, and they can reach densities that are even greater than those of the species they parasitize (Rothstein 1990, Davies 2000). At high densities, female generalist brood parasites may exhibit little or no territoriality during the breeding season, and this can lead to extensive overlap of the laying ranges of individual females (Elliott 1980, Strausberger and Ashley 2003). When females overlap their laying ranges, host nests may be multiply parasitized and contain parasitic eggs that belong to more than one female (Payne 1977, Fleischer and Smith 1992, Martinez et al. 1998, Alderson et al. 1999, Schuetz 2005, Ellison et al. 2006).

The Brown-headed Cowbird (Molothrus ater; hereafter "cowbird") is one of the most generalized brood parasites in the world, having been raised by at least 172 different hosts (Friedmann and Kiff 1985, Ortega 1998, Lowther 2011). The cowbird is a host generalist on both individual and population levels, capable of parasitizing a wide range of host species within a community (Hahn and Hatfield 1995, Strausberger and Ashley 1997, Rivers et al. 2010b), and individual females may use several host species to raise their young (Hahn and Hatfield 1995, Alderson et al. 1999, Strausberger and Ashley 2005). Although we know much about cowbird-host interactions, we know markedly less about the relatedness of cowbird offspring that are raised together in multiply parasitized nests. Available data indicate that multiply parasitized nests occur because the same female re-lays in a single nest, multiple females lay eggs in a single nest, or both (i.e., Alderson et al. 1999, Hahn et al. 1999, McLaren et al. 2003, Ellison et al. 2006). It should be noted, however, that previous studies have been conducted in host communities where cowbirds occured at low to moderate breeding densities and the associated host community experienced relatively low rates of parasitism (i.e., mean parasitism $=5-31 \%$ of all host nests). This contrasts markedly with high-density populations located in the Great Plains, which represent the cowbird's historical breeding range. For example, Breeding Bird Survey (BBS) data indicate that the relative abundance of cowbirds along BBS routes in Kansas (35.4 individuals) are nearly $3 \times$ greater than over the remainder of its entire range (12.7 individuals; Sauer et al. 2008). High breeding densities often lead to intense competition for host nests, as evidenced by high levels of multiple parasitism and extensive use of the available hosts in the community (Elliott 1978; Zimmerman 1983; Ortega 1998; Rivers et al. 2003, 2010b; Jensen and Cully 2005). In some areas of the Great Plains, competition for host nests may be so great that a portion of host nests contain more parasitic offspring than can be raised during a single nesting attempt (Elliott 1978, Zimmerman 1983, Ortega 1998). Thus, studying high-density populations in the Great Plains region offers a unique perspective on cowbird-host interactions in relation to previously studied populations, especially with regard to multiple parasitism of host nests and the resulting interactions among cowbird offspring that are raised together.

In the present study, our first objective was to quantify the relatedness of cowbird offspring that were found together in multiply parasitized nests in a heavily parasitized host community in northeastern Kansas (Rivers et al. 2010b). The cowbird is the secondmost-abundant breeding passerine at our primary study site (Konza Prairie) based on long-term population monitoring of passerine birds (Rivers et al. 2010a), and cowbirds in this area are known to parasitize nests of nearly two dozen nonrejecting hosts, many of which receive multiple cowbird eggs (Elliott 1978, Zimmerman 1983, Jensen and Cully 2005, Rivers et al. 2010b). Therefore, our second objective was to examine the extent to which multiple parasitism was influenced by nest availability and community-wide parasitism patterns across the breeding season (see Strausberger 1998). Understanding the factors that lead to multiple parasitism of host nests is important because multiple parasitism has important fitness consequences for laying cowbirds, particularly because hosts vary in the number of cowbird young that they can produce when parasitized (Kilpatrick 2002, Kosciuch and Sandercock 2008). In addition, multiple parasitism has strong implications for the survival of parasitic offspring because parasitic young are often the strongest competitors for parental care in host nests (Dearborn 1998, Lichtenstein and Sealy 1998, Kilner 2003, Kilner et al. 2004) through their exaggerated begging behaviors (Briskie et al. 1994, Dearborn 1998, Rivers 2007). Finally, because hosts can raise only a finite number of offspring, examining the degree of multiple parasitism in host nests can provide insight into the factors that influence laying decisions of females. Therefore, we round out our investigation by using community-wide parasitism data to assess whether multiple parasitism may have resulted from constrained laying opportunities of females that stemmed from a high degree of competition for host nests.

\section{Methods}

Study location.-During the 2003-2006 breeding seasons, we opportunistically collected samples for genetic analysis from cowbird offspring found in multiply parasitized host nests in northeastern Kansas. The majority of data ( $n=54$ host nests) were collected during field work at the 3,487-ha Konza Prairie Biological Station, a tallgrass prairie site that has a high density of breeding cowbirds (Zimmerman 1993, Rivers et al. 2010a). Konza Prairie is divided into 60 watersheds, with different fire and grazing treatments applied to each watershed to reflect the range of natural disturbance events. Additional samples ( $n=3$ host nests) were collected from nests located at Fort Riley Military Installation, a U.S. Army training area that is $\sim 10 \mathrm{~km}$ from Konza Prairie. Fort Riley also harbors a high density of cowbirds and supports a very similar host community (Rivers et al. 2010a). At Konza Prairie, we searched for host nests using a combination of behavioral cues and systematic searches (Martin and Geupel 1993); on a limited number of occasions, we also used rope dragging to find nests of ground-nesting birds. Rope dragging was also used to locate host 
nests at Fort Riley for an unrelated research project. Although logistical considerations necessitated sampling a subset of the host community, we have no reason to believe that the genetic data presented here are unrepresentative of the local host community in our study area. Indeed, a long-term, community-level study of cowbird parasitism at Konza Prairie that examined $>3,000$ host nests found that multiple parasitism was not biased toward the host species from which genetic samples were obtained for our study, because nearly all host species at Konza Prairie experience multiple parasitism (Rivers et al. 2010b; see below). Finally, we used long-term parasitism data from the host community to quantify the degree of multiple parasitism for all nonrejecting cowbird hosts, which allowed us to explore the degree of competition for host nests experienced by cowbirds.

Analysis of genetic data.-Samples of cowbird offspring for genetic analysis were taken from egg (embryo, yolk spot, or eggshell, $n=76)$ and nestling tissue $(n=56)$ stored in $70 \%$ alcohol after collection, and from nestling blood samples $(n=68)$ stored in Queen's Lysis buffer. In addition, blood was sampled from 68 adult cowbirds from Konza Prairie prior to lethal collection for an unrelated project (Kosciuch and Sandercock 2008). All samples were collected under appropriate institutional, state, and federal permits. DNA was isolated from each sample using a Qiagen kit, following the manufacturer's protocol (Qiagen, Valencia, Califor-

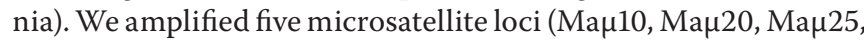
$\mathrm{Ma} \mu 29 \mathrm{~b}$, and $\mathrm{Dp} \mu 16$ ), following the general amplification profiles from Alderson et al. (1999), but a fluorescent-labeled primer was included in the reaction mix and the resultant products of polymerase chain reaction were analyzed on an ABI 3100 DNA analyzer (Applied Biosystems, Foster City, California). Chromatograms were processed in GENESCAN (Applied Biosystems), and estimates of fragment sizes were made in GENEMAPPER (Applied Biosystems). Allele frequencies, heterozygosities, and significance of deviations from expectations of Hardy-Weinberg equilibrium were calculated in GENEPOP (Raymond and Rousset 1995, Rousset 2008). We also amplified and sequenced a part of the mtDNA control region from each sample using the H417 and LGL2 primers from Tarr (1995), totaling 343 base pairs. Because mtDNA haplotype data function as variable markers that indicate kinship, we were able to use mtDNA as a haploid, maternal marker that allowed for a more accurate assignment of relatedness than if we had relied on microsatellite data alone.

Within each multiply parasitized nest, we examined the relatedness among all possible pairs of cowbird offspring for which we had conclusive genetic data; samples that had no power to detect relatedness were excluded from this analysis (see below). For example, a nest containing four cowbird offspring (e.g., A, B, C, and $D$ ) would result in six possible pairings (i.e., A-B, A-C, A-D, B-C, B-D, C-D). We conducted analyses for each nest, and then summarized the values from all sampled nests. We used KINSHIP, version 1.3.1 (Queller and Goodnight 1989), to assess relatedness of offspring in multiply parasitized nests, including the allele frequencies calculated by GENEPOP from the independent sample of 68 adults from the study site. For each pair of offspring, we used KINSHIP to calculate $R$ (i.e., the average genetic relatedness) and tested the observed values for $R$ against the null hypothesis of no relatedness between offspring (i.e., $R=0$ ) and the alternative hypothesis of full siblings $(R=0.5)$. We did this by comparing the calculated values for $R$ with a distribution of $R$ values that was generated by simulation using the multilocus genotype of the individual and the allele frequencies of the population; we used $\alpha=0.01$ to reduce the likelihood of a Type II error. The program KINSHIP allows use of haploid, maternally inherited markers to be used in calculations of relatedness. As with other markers, the frequency of an allele (or haplotype) enters into the calculation of the likelihood of $R$, given the data. Therefore, we were able to conduct our analyses using genotypes of the five microsatellite loci combined with the mtDNA haplotype data to increase our ability to quantify the relatedness among cowbird offspring found sharing a nest.

Analysis of parasitism data.-To explore factors that may have contributed to multiple parasitism of host nests at Konza Prairie, we first examined the general pattern of nest initiation date, mean parasitism rate, and the timing of multiple parasitism in host nests across the breeding season. We restricted this analysis to the 2003 and 2005 breeding seasons because the majority of our genetic data (43 of 57 [75.4\%] multiply parasitized nests) were collected during those years. We excluded nests from two potential hosts, the Brown Thrasher (Toxostoma rufum) and Gray Catbird (Dumetella carolinensis), because these species regularly reject cowbird eggs (Rothstein 1975) and including their nests would negatively bias our estimates of parasitism. For the remaining hosts, we determined the laying date of the first egg in each nest (hereafter "nest initiation date") and the number of cowbird eggs and/or nestlings observed in the nest (hereafter "cowbird offspring"). If nests were found after laying ceased and we did not know the hatching date (e.g., because of nest predation during incubation), we estimated the initiation date as the midpoint between the earliest and latest possible hatching dates, assuming that hosts laid modal clutch sizes as reported by Baicich and Harrison (1997). Unfortunately, we were unable to quantify nest survival for most host nests because additional research on cowbird-host interactions required the manipulation of nest contents and may have biased survival rates (e.g., Kosciuch et al. 2006, Rivers 2007). We used Poisson rate regression with a log link to investigate whether the maximum number of cowbird offspring was associated with nest initiation date, and to examine whether the number of laying females and re-laying females varied with nest initiation date. In addition, we examined whether the degree of parasitism was associated with the peak of nesting in each year by quantifying the relationship between the number of new nests initiated and the mean number of cowbird offspring in parasitized nests across the breeding season, using 5-day intervals that contained at least 10 new nests. Finally, we examined nesting data from a long-term study of cowbird parasitism at Konza Prairie from 2002 to 2007 (see Rivers et al. 2010b) to quantify the degree of multiple parasitism of host nests, to give insight into the degree of competition for host nests experienced by cowbirds. The significance level for all statistical tests was $P<0.05$.

\section{Results}

Quality and quantity of genetic data.-Sufficient microsatellite data were obtained from 160 offspring samples (of 200 tissue, blood, or eggshell samples attempted) and all 68 adult samples. Microsatellites were highly variable in the adult samples, ranging from 8 to 27 alleles per locus (mean of 15) and with an average 
TABLE 1. Characteristics of the 5 microsatellite loci genotyped from a sample of 68 adult Brown-headed Cowbirds used to analyze the relatedness of cowbird offspring in multiply parasitized nests in northeastern Kansas. $H_{(o b s)}$ indicates observed heterozygosity for each locus.

\begin{tabular}{|c|c|c|c|c|}
\hline Locus & $\begin{array}{l}\text { Alleles } \\
(n)\end{array}$ & $\begin{array}{l}\text { Fequency of } \\
\text { common allele }\end{array}$ & $H_{\text {(obs) }}$ & $\begin{array}{l}P \text { value from Hardy- } \\
\text { Weinberg equilibrium }\end{array}$ \\
\hline Ман10 & 8 & 0.403 & 0.791 & 0.77 \\
\hline Ман20 & 20 & 0.129 & 0.848 & 0.36 \\
\hline Ман25 & 27 & 0.119 & 0.970 & 0.88 \\
\hline Dpн16 & 8 & 0.412 & 0.662 & 0.69 \\
\hline Ман29b & 21 & 0.152 & 0.879 & 0.10 \\
\hline
\end{tabular}

observed heterozygosity of $83 \%$ (Table 1). Across all 228 adult and offspring samples, the number of alleles per locus ranged from 8 to 34 (mean of 19). All loci in the adult samples were in HardyWeinberg equilibrium (all $P \geq 0.10$ ), which suggests the absence of null alleles and allelic dropout. Only the adult samples were used for allele frequency calculations. Sufficient mtDNA control-region sequence data were obtained from 196 offspring and 62 adult samples (Table 2). A total of 16 haplotypes were found among the 258 mtDNA sequences, defined by bases at 13 variable sites. Of these, 4 haplotypes were very common and were found in 85,45 , 27 , and 25 individuals. Three of the less common haplotypes found in adults were not found in offspring, and 5 haplotypes found in offspring were not found in adults. A total of 38 offspring had mtDNA sequence data but insufficient microsatellite data.

Sufficient data for genetic analysis were obtained from 68 adult cowbirds and from 160 cowbird offspring. The offspring occurred within 67 multiply parasitized nests, but only 57 of these yielded sufficient genetic data for at least 2 cowbird offspring (i.e., 10 multiply parasitized nests yielded data for only 1 cowbird offspring). The 57 nests were distributed among six host species: Dickcissel ( $n=33$ nests), Field Sparrow $(n=11)$, Eastern
Meadowlark $(n=1)$, Eastern Towhee $(n=1)$, Bell's Vireo $(n=4)$, and Red-winged Blackbird ( $n=7$ ) (for scientific names of host species, see Table 3 ). The number of cowbird offspring successfully genotyped from the 57 multiply parasitized nests ranged from 2 to 6 ( 2 offspring sampled: $n=36$ nests; 3 offspring sampled: $n=12$ nests; 4 offspring sampled: $n=5$ nests; 5 offspring sampled: $n=3$ nests; 6 offspring sampled: $n=1$ nest).

Kinship analysis.-We conducted likelihood analyses of relatedness using the 5 microsatellite loci and mtDNA sequence for 147 pairs of offspring from within the 57 nests. Of these, 94 pairings (64\%) had sufficient power at $P<0.01$ to detect differences from either the null $(R=0)$ or the alternative $(R=0.5)$ hypothesis, so we limited our comparisons to these pairings. Of these, $R$ did not differ from zero for 56 pairings yet differed from 0.5 (i.e., pairings were not full siblings). $R$ values for the other 38 pairings were not significantly different from $R=0.5$ but differed significantly from $R=0$ (i.e., pairings were full siblings). The mean $( \pm$ SE) value of relatedness $(R)$ for the related pairs was $0.65 \pm 0.063$ (range: $0.30-1.00$ ), which indicates that they were full siblings. Taken together, this indicates that the mean likelihood that an individual cowbird, found in a multiply parasitized nest, shared a nest with a full sibling was $40.4 \%$ (95\% confidence interval: $28.4-52.4 \%$ ). This estimate should be taken as a minimum estimate of relatedness, given that we did not have the power to differentiate half-siblings in our data.

The combined use of microsatellites and mtDNA sequence data substantially improved our kinship assessments. When we used only the 5 microsatellite loci in the KINSHIP analysis, 98 of the 147 had sufficient power to detect differences from either hypothesis, and $30.6 \%$ of the offspring pairs were not significantly different from 0.5 but were significantly different from zero. It is possible we missed some sibling pairings, given our conservative cutoff of $P<0.01$. However, conducting the analysis using an alpha value of 0.05 resulted in $96.6 \%$ with sufficient power to differentiate, and $36.6 \%$ of the comparisons did not result in a rejection of

TABLE 2. The 13 variable sites (from 343 base pairs) for the 16 mtDNA control-region haplotypes found among 196 offspring and 62 adult Brownheaded Cowbirds from northeastern Kansas. A period indicates the same base as in Haplotype A, and the final two columns contain the number of samples with each haplotype for adult blood and offspring samples. "Site" is the number of base pairs from the 3' end of the H417 primer.

\begin{tabular}{|c|c|c|c|c|c|c|c|c|c|c|c|c|c|c|c|}
\hline \multirow[b]{2}{*}{ Haplotype } & \multicolumn{13}{|c|}{ Site } & \multirow{2}{*}{$\begin{array}{l}\text { Adults } \\
(n)\end{array}$} & \multirow{2}{*}{$\begin{array}{c}\text { Offspring } \\
(n)\end{array}$} \\
\hline & 88 & 135 & 146 & 153 & 168 & 181 & 240 & 251 & 253 & 257 & 262 & 266 & 300 & & \\
\hline A & $\mathrm{T}$ & G & $\mathrm{T}$ & $\mathrm{T}$ & A & $\mathrm{T}$ & G & $\mathrm{T}$ & G & G & G & A & A & 7 & 18 \\
\hline B & $\mathrm{C}$ & . & . & . & G & . & A & . & . & . & . & G & . & 9 & 36 \\
\hline $\mathrm{C}$ & . & . & $\mathrm{C}$ & . & . & . & . & . & . & . & . & . & . & 0 & 3 \\
\hline $\mathrm{D}$ & C & . & . & . & . & . & . & . & . & . & . & . & G & 0 & 2 \\
\hline$E$ & $\mathrm{C}$ & . & . & . & . & . & . & . & . & . & . & . & . & 20 & 65 \\
\hline $\mathrm{F}$ & $\mathrm{C}$ & . & . & C & . & . & . & . & . & . & . & . & . & 8 & 19 \\
\hline G & $\mathrm{C}$ & . & . & . & G & $\mathrm{C}$ & A & . & A & . & . & G & . & 0 & 4 \\
\hline $\mathrm{H}$ & $\mathrm{C}$ & . & . & . & G & . & . & . & . & . & . & . & . & 4 & 14 \\
\hline I & $\mathrm{C}$ & . & . & . & G & . & A & . & A & . & . & G & . & 0 & 14 \\
\hline$J$ & $\mathrm{C}$ & . & . & . & . & . & . & C & . & . & . & . & . & 0 & 2 \\
\hline K & C & . & . & . & 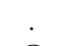 & . & . & . & . & . & A & . & . & 5 & 10 \\
\hline $\mathrm{N}$ & C & . & . & . & G & C & A & . & . & . & 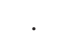 & G & . & 1 & 6 \\
\hline $\mathrm{O}$ & C & $\mathrm{T}$ & . & . & 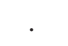 & . & . & . & . & . & . & 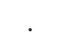 & . & 1 & 0 \\
\hline $\mathrm{P}$ & C & . & . & . & . & . & . & . & . & $A$ & . & . & . & 1 & 0 \\
\hline $\mathrm{Q}$ & C & . & . & . & G & . & A & . & . & 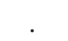 & $A$ & G & . & 5 & 3 \\
\hline $\mathrm{R}$ & C & . & . & $\mathrm{C}$ & G & . & A & . & . & . & . & G & . & 1 & 0 \\
\hline
\end{tabular}


TABLE 3. The distribution of multiple parasitism for nonrejecting cowbird hosts at Konza Prairie, northeastern Kansas, during the 2002-2007 breeding seasons.

\begin{tabular}{|c|c|c|c|c|c|c|c|c|c|c|}
\hline \multirow[b]{2}{*}{ Host species } & \multicolumn{8}{|c|}{ Brown-headed Cowbird offspring per nest $(n)$} & \multirow{2}{*}{$\begin{array}{l}\text { Nests } \\
(n)\end{array}$} & \multirow{2}{*}{$\begin{array}{c}\text { Percentage of } \\
\text { parasitized nests with } \\
\geq 2 \text { cowbird offspring }\end{array}$} \\
\hline & 0 & 1 & 2 & 3 & 4 & 5 & 6 & 7 & & \\
\hline Dickcissel (Spiza americana) & 271 & 236 & 207 & 95 & 53 & 22 & 4 & 2 & 890 & 61.9 \\
\hline Bell's Vireo (Vireo bellii) & 203 & 245 & 200 & 34 & 7 & 0 & 0 & 0 & 689 & 49.6 \\
\hline Red-winged Blackbird (Agelaius phoeniceus) & 523 & 75 & 46 & 19 & 3 & 3 & 1 & 0 & 670 & 49.0 \\
\hline Field Sparrow (Spizella pusilla) & 72 & 32 & 32 & 4 & 1 & 0 & 0 & 0 & 141 & 53.6 \\
\hline Eastern Meadowlark (Sturnella magna) & 49 & 7 & 7 & 3 & 0 & 0 & 1 & 0 & 67 & 61.1 \\
\hline $\begin{array}{l}\text { Grasshopper Sparrow (Ammodramus } \\
\text { savannarum) }\end{array}$ & 24 & 14 & 6 & 1 & 1 & 0 & 0 & 0 & 46 & 36.4 \\
\hline Eastern Phoebe (Sayornis phoebe) & 27 & 3 & 1 & 0 & 1 & 1 & 0 & 0 & 33 & 50.0 \\
\hline Lark Sparrow (Chondestes grammacus) & 5 & 5 & 4 & 1 & 2 & 0 & 0 & 0 & 17 & 58.3 \\
\hline Eastern Towhee (Pipilo erythrophthalmus) & 0 & 1 & 3 & 6 & 2 & 1 & 2 & 0 & 15 & 93.3 \\
\hline Northern Cardinal (Cardinalis cardinalis) & 5 & 4 & 4 & 1 & 1 & 0 & 0 & 0 & 15 & 60.0 \\
\hline Orchard Oriole (Icterus spurius) & 0 & 2 & 2 & 0 & 2 & 0 & 1 & 0 & 7 & 71.4 \\
\hline Blue Grosbeak (Passerina caerulea) & 0 & 0 & 3 & 1 & 0 & 0 & 0 & 0 & 4 & 100.0 \\
\hline Eastern Bluebird (Sialia sialis) & 3 & 1 & 0 & 0 & 0 & 0 & 0 & 0 & 4 & 0.0 \\
\hline Yellow Warbler (Setophaga petechia) & 0 & 3 & 0 & 1 & 0 & 0 & 0 & 0 & 4 & 25.0 \\
\hline House Finch (Carpodacus mexicanus) & 2 & 1 & 0 & 0 & 0 & 0 & 0 & 0 & 3 & 0.0 \\
\hline Bobolink (Dolichonyx oryzivorus) & 2 & 0 & 0 & 0 & 0 & 0 & 0 & 0 & 2 & 0.0 \\
\hline Blue-gray Gnatcatcher (Polioptila caerulea) & 0 & 1 & 0 & 0 & 0 & 0 & 0 & 0 & 1 & 0.0 \\
\hline Common Yellowthroat (Geothlypis trichas) & 0 & 1 & 0 & 0 & 0 & 0 & 0 & 0 & 1 & 0.0 \\
\hline Henslow's Sparrow (Ammodramus henslowii) & 0 & 0 & 0 & 0 & 1 & 0 & 0 & 0 & 1 & 100.0 \\
\hline Indigo Bunting (Passerina cyanea) & 0 & 0 & 0 & 1 & 0 & 0 & 0 & 0 & 1 & 100.0 \\
\hline Louisiana Waterthrush (Parkesia motacilla) & 1 & 0 & 0 & 0 & 0 & 0 & 0 & 0 & 1 & 0.0 \\
\hline Total nests & 1,187 & 631 & 515 & 167 & 74 & 27 & 9 & 2 & 2,612 & \\
\hline
\end{tabular}

the hypothesis that nestmates were full siblings. This result was close to that found when we used our conservative alpha of 0.01 , so it was unlikely that we missed any sibling pairings.

There were 17 additional nests with insufficient microsatellite data for kinship analysis of at least 2 offspring, but for which the mtDNA haplotypes of all nestmates could be compared. On the basis of simple match-mismatch analysis, 5 of 10 nests containing 2 cowbird offspring were attributable to different females. Among three-offspring nests, 2 had all offspring with identical haplotypes (suggesting 1 female) and 3 had 2 offspring matching (suggesting 2 females). We assessed 2 four-offspring nests, of which 1 had evidence of 2 females and 1 had evidence of 3 . In addition, of 31 sibships resolved from microsatellite data only, and for which both members of a pair had mtDNA haplotypes, only 7 (22.6\%) did not share identical mtDNA haplotypes (these 7 could be half-sibs from the same father and a different mother). By contrast, 50 of 57 pairs (87.7\%) considered unrelated by microsatellites had nonmatching mtDNA haplotypes $\left(\chi^{2}=37.3, P<0.0001\right)$. Thus, the mtDNA haplotypes, which are maternally inherited, strongly support the sibling designations based on microsatellite genotype (whether full or maternal half-siblings). On the basis of the combined microsatellite and mtDNA haplotype analysis, $71.4 \%$ of nests with power to detect differences contained offspring from $>1$ female, and there were as many as 9 cases in which at least 3 females may have parasitized a nest. The most heavily parasitized nest contained 7 cowbird offspring, of which we were able to genotype 6; of these, 3 were likely laid by a single female, 2 by a second female, and 1 by a third female. It is possible, on the basis of mtDNA haplotype, that the seventh offspring, with insufficient microsatellite genotypes for kinship analysis, was tied to the female that laid 3 eggs (as all 4 offspring had haplotype I; see Table 2).

Timing of parasitism and degree of multiple parasitism.During the 2003 and 2005 breeding seasons, respectively, 179 of 295 (60.7\%) and 279 of 497 (56.1\%) nonrejecting host nests were parasitized by cowbirds, with 1 to 6 cowbird offspring per parasitized nest. In both years, the majority of cowbird offspring were observed sharing the nest with at least 1 other cowbird (2003: $76.3 \%$, 254 of 333 offspring; 2005: 72.2\%, 348 of 482 offspring). The mean proportion of available host nests that were parasitized increased steeply at the onset of both breeding seasons and then either slowly declined (Fig. 1A) or was maintained until the end of the breeding season (Fig. 1B). By contrast, the number of newly initiated host nests stayed relatively constant during most of each breeding season (Fig. 1). The number of cowbird offspring per nest was associated with nest initiation date in 2005 (Wald statistic: $\chi^{2}=18.9, \mathrm{df}=1, P<0.001$ ) but not in 2003 (Wald statistic: $\chi^{2}=1.50$, $\mathrm{df}=1, P=0.221)$. However, in both years no relationship was detected between the number of new nests initiated and the parasitism level of parasitized nests (2003: $r=0.11, P=0.736$; 2005 : $r=0.37, P=0.242$ ), indicating that the greatests levels of multiple parasitism did not correspond to the peak of nesting activity (Fig. 2). For a subset of parasitized nests at Konza Prairie for which we were able to estimate the number of laying females, we detected no relationship between the number of females laying in a nest 

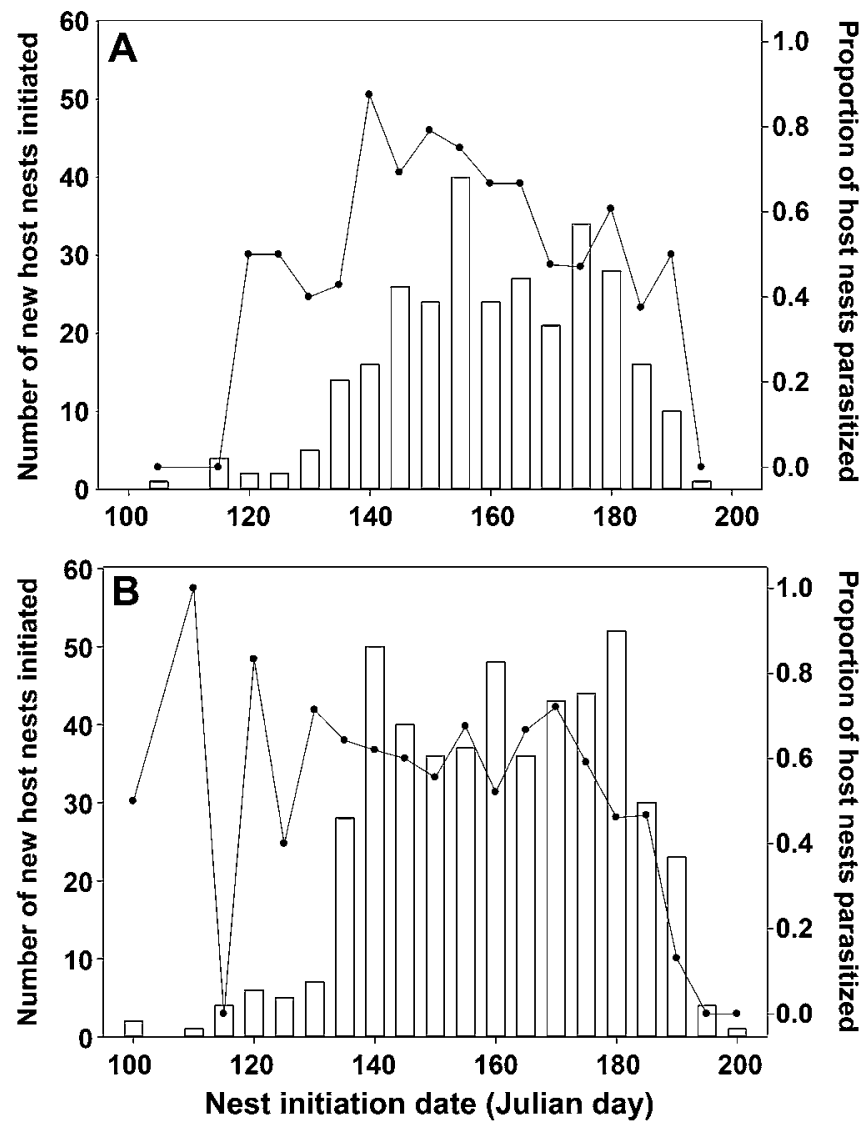

FIG. 1. The number of new, nonrejecting host nests initiated at Konza Prairie (bars) and the proportion of host nests that were parasitized by Brown-headed Cowbirds during the same period (line segments) during the (A) 2003 and (B) 2005 breeding seasons. Note that Julian day 121 corresponds to 1 May.

and the nest initiation date (likelihood ratio test: $\chi^{2}=0.19, \mathrm{df}=1$, $P=0.660)$. In addition, we did not detect a relationship between the number of re-laying females in a parasitized nest and nest initation date (likelihood ratio test: $\chi^{2}=0.24, \mathrm{df}=1, P=0.625$ ). Finally, all of the 11 most abundant hosts in the community $(n \geq 7$ nests per host species) were multiply parasitized during 20022007 , with the percentage of parasitized nests containing $\geq 2$ cowbird offspring ranging from $36.4 \%$ to $93.3 \%$ across species (Table 3). During 2002-2007, the majority of cowbird offspring in nonrejecting host nests shared their nest with at least 1 other cowbird (76.3\%; 2,030 of 2,661 offspring in 2,612 nests; Table 3).

\section{Discussion}

Our data revealed that the likelihood that 2 cowbird offspring sharing a multiply parasitized nest were full siblings was $>40 \%$. This estimate should be taken as a minimum estimate of relatedness because we did not have the power to differentiate halfsiblings in our data set, and there is some evidence that female cowbirds in our population mate with multiple males (Elliott 1980). Together, our findings that $>40 \%$ of cowbird offspring were raised alongside full siblings and that the majority of cowbird
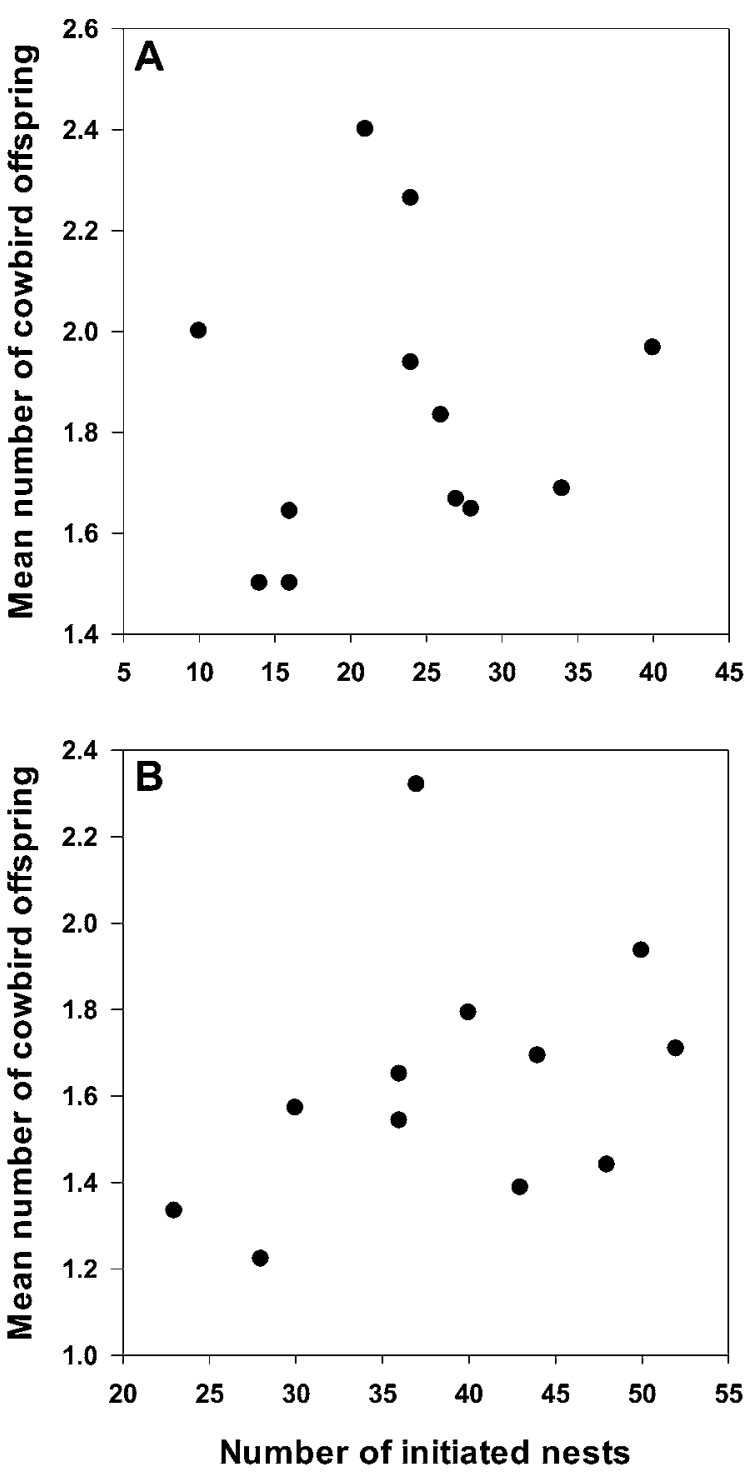

FIG. 2. Mean number of Brown-headed Cowbird offspring in parasitized host nests plotted against the number of new, nonrejecting host nests initiated at Konza Prairie during the (A) 2003 and (B) 2005 breeding seasons. Each point represents a unique 5 -day interval in which at least 10 nests were initiated.

offspring on our study site were found in nests with at least one other cowbird indicate that many cowbirds on our study site shared their nest with close relatives because of re-laying by females. The sharing of the nest with close relatives by parasitic young could have important implications for the evolution of begging behavior in parasitic offspring (Rivers 2008). Theoretical models of begging by parasitic young are based on the premise that the parasite is raised either alone or alongside unrelated host nestmates, leading to vigorous and exaggerated begging behavior (Motro 1989, Holen et al. 2001). However, if parasitic offspring share the nest with close relatives, their begging displays may be reduced in intensity because offspring selfishness is predicted to be constrained when individuals are raised alongside close 
relatives (Godfray 1995, Kilner 2005). Although it was beyond the scope of our study to investigate how relatedness influenced selfishness by brood-parasitic young, additional work in this study population is focused on this topic (Rivers 2008) and should provide insights germane to parent-offspring conflict theory, especially for understanding the limits of selfishness between kin (Godfray 1995) and whether the behavior of parasitic offspring is similarly constrained by relatedness (Kilner 2005).

Multiple parasitism by cowbirds in our study was attributed to a combination of multiple females laying in nests and to individual females re-laying in the same nest, a result that is similar to laying patterns found in previous studies of multiple parasitism in areas of lower cowbird density (Alderson et al. 1999, Hahn et al. 1999, McLaren et al. 2003, Ellison et al. 2006). Unlike the results of previous studies, however, our data revealed that $19.6 \%(11 / 56)$ of the nests in the present study were parasitized by $\geq 3$ females whereas only 1 or 2 laying females per nest had previously been documented. This result indicates that laying ranges of females overlapped extensively at Konza Prairie and suggests a strong link between the high cowbird density at this site and the prevalence of multiple females placing their eggs in the same nest. Our previous analysis of long-term nesting data found high levels of parasitism throughout hosts in this community (Rivers et al. 2010b), and additional data presented here indicate that multiple parasitism is common for nearly all cowbird hosts at Konza Prairie. In some cases, a substantial portion of parasitized nests contained $\geq 2$ cowbird offspring (Table 3), which suggests a high degree of competition for host nests by females. We suspect that this may be a general attribute of high-density cowbird populations in the Great Plains region, and such strong competition may play an important role in structuring other populations as well (Chace et al. 2005).

Cowbird parasitism at Konza Prairie was high across the breeding season and followed the general pattern noted in previous studies of this area (Elliott 1978, Zimmerman 1983, Jensen and Cully 2005). This is perhaps not surprising, given that the cowbird is a generalist brood parasite and must time its laying to coincide with the period during which the majority of hosts are breeding (Scott 1963, Finch 1983). In addition, the degree of parasitism was consistently high across the breeding season and was not related to the number of newly initiated host nests. Furthermore, neither the number of available host nests nor the nest initiation date appeared to influence the number of females laying in parasitized nests. Collectively, this suggests that female cowbirds faced strong competition for laying opportunities in host nests throughout the breeding season. However, it should be noted that the Dickcissel, a preferred host at Konza Prairie, breeds later in the season than other cowbird hosts (Zimmerman 1993), so temporal changes in Dickcissel nest availability might also be an important influence on the laying decisions of females (see Rivers et al. 2010b).

One important question that emerges from our investigation is whether females in our population were constrained by competition for host nests, which led them to make the "best of a bad situation" and lay multiple eggs in individual nests. Re-laying in host nests could be adaptive if females re-lay in host species that can raise multiple cowbird offspring in a single breeding attempt. Our data from Konza Prairie indicate that the Dickcissel is a preferred host (Rivers et al. 2010b), and other studies in northeastern Kansas have found that this host can raise up to five cowbirds from a single nest (Hatch 1983, Rivers et al. 2003). Thus, multiple parasitism might be adaptive if laying females target either the Dickcissel or other hosts that can raise multiple cowbirds during a nesting attempt. Unfortunately, we currently lack data that allow us to rigorously test this idea across the entire host community, so the extent to which re-laying in host nests reflects adaptive decisions by females remains unknown.

In contrast to an adaptive explanation for re-laying, our data indicate that, in at least some cases, re-laying in host nests is due to constraints on females. In particular, multiple-parasitism data from Konza Prairie indicate that the number of cowbird offspring observed in some host nests regularly exceeded the number of young that hosts can raise in a single breeding attempt. The Bell's Vireo, a regularly parasitized cowbird host at this site, is noteworthy in this regard because it is one of the smallest cowbird hosts and is unable to raise more than one cowbird when parasitized (Parker 1999, Kosciuch and Sandercock 2008). Nevertheless, $49.6 \%$ of the parasitized vireo nests ( $n=486$ nests; Table 3 ) that we located through intensive nest-searching efforts contained at least two cowbird offspring, and our genetic analysis indicates that some multiply parasitized vireo nests contained multiple cowbird offspring that were attributed to a single female (J. W. Rivers et al. unpubl. data). Additionally, the extent of parasitism on the vireo declines after the preferred and abundant Dickcissel begins to breed on the study site (Rivers et al. 2010b), which suggests that multiple parasitism of and re-laying in vireo nests at Konza Prairie stem from constraints on laying females in their ability to find suitable host nests, especially during the early part of the breeding season. That a high cowbird density and shortage of host nests leads to multiple parasitism and re-laying in vireo nests is supported by the finding that vireos are unlikely to experience multiple parasitism in areas where cowbird populations have been reduced by lethal control measures (Kus et al. 2010). We suspect that this same explanation extends to other hosts in the community, because other hosts are known to be parasitized with more cowbird offspring than can be raised in a single nesting attempt (e.g., $\leq 9$ cowbird eggs in a Dickcissel nest; Zimmerman 1983). If most female cowbirds are indeed constrained in their laying decisions, this would indicate that the Konza Prairie host community is saturated and that the high density of laying females leads to strong competition for host nests, elevated levels of multiple parasitism, and re-laying in host nests by individual females, which forces females to "make the best of a bad situation." Despite this intriguing idea, additional research on this topic is needed for better resolution of this issue, and future efforts should focus on addressing how female cowbirds make laying decisions, determining whether particular females (e.g., first-year breeders) are constrained in their egg laying, and quantifying how individual laying decisions change across the breeding season, especially with respect to the timing of breeding by the Dickcissel.

\section{ACKNOWLEDGMENTS}

Financial support was provided by the American Ornithologists' Union, Animal Behavior Society, Chapman Fund of the American Museum of Natural History, Cooper Ornithological Society, Helmetcamera.com, Sigma Xi Honor Society, Los Angeles Audubon Society, the Graduate Division and the Academic Senate at the University of California, Santa Barbara, the National Science 
Foundation (NSF) Doctoral Dissertation Improvement Grant program (IOB-0608263), the NSF Long-Term Ecological Research Program at Konza Prairie Biological Station, and the Smithsonian Institution's Center for Conservation and Evolutionary Genetics. We thank M. Blundell, J. Hite, W. Janousek, A. Lyon, E. McCarthy, R. Rehmeier, B. Sandercock, and B. Van Korff for assistance in locating nests, B. K. Sandercock for extensive logistical support, C. McIntosh and N. Rotzel for facilitation of laboratory work at the Smithsonian, W. E. Jensen, P. Klug, K. L. Kosciuch and E. Hewett for sharing parasitism data, T. M. Loughin for statistical advice, and J. V. Briskie, B. D. Peer, J. C. Reboreda, S. I. Rothstein, and several anonymous reviewers for helpful comments on the manuscript.

\section{Literature Cited}

Alderson, G. W., H. L. Gibbs, and S. G. Sealy. 1999. Determining the reproductive behavior of individual Brown-headed Cowbirds using microsatellite DNA markers. Animal Behaviour 58:895-905.

Baicich, P. J., And J. O. Harrison. 1997. A Guide to the Nests, Eggs, and Nestlings of North American Birds, 2nd ed. Academic Press, San Diego, California.

Briskie, J. V., C. T. Naugler, and S. M. Leech. 1994. Begging intensity of nestling birds varies with sibling relatedness. Proceedings of the Royal Society of London, Series B 258:73-78.

Chace, J. F., C. Farmer, R. Winfree, D. R. Curson, W. E. Jensen, C. B. Goguen, And S. K. Robinson. 2005. Cowbird (Molothrus spp.) ecology: A review of factors influencing distribution and abundance of cowbirds across spatial scales. Pages 45-70 in Management of Cowbirds and Their Hosts: Balancing Science, Ethics, and Mandates (C. P. Ortega, J. F. Chace, and B. D. Peer, Eds.). Ornithological Monographs, no. 57.

Davies, N. B. 2000. Cuckoos, Cowbirds and Other Cheats. Princeton University Press, Princeton, New Jersey.

Dearborn, D. C. 1998. Begging behavior and food acquisition by Brown-headed Cowbird nestlings. Behavioral Ecology and Sociobiology 43:259-270.

Elliot T, P. F. 1978. Cowbird parasitism in the Kansas tallgrass prairie. Auk 96:161-167.

Elliott, P. F. 1980. Evolution of promiscuity in the Brown-headed Cowbird. Condor 82:138-141.

Ellison, K., S. G. Sealy, And H. L. Gibbs. 2006. Genetic elucidation of host use by individual sympatric Bronzed Cowbirds (Molothrus aeneus) and Brown-headed Cowbirds (M. ater). Canadian Journal of Zoology 84:1269-1280.

FincH, D. M. 1983. Brood parasitism of the Abert's Towhee: Timing, frequency, and effects. Condor 85:355-359.

Fleischer, R. C., And N. G. Smith. 1992. Giant Cowbird eggs in the nests of two icterid hosts: The use of morphology and electrophoretic variants to identify individuals and species. Condor 94:572-578.

Friedmann, H., And L. F. Kiff. 1985. The parasitic cowbirds and their hosts. Proceedings of the Western Foundation of Vertebrate Zoology 2:226-302.

Godfray, H. C. J. 1995. Signaling of need between parents and young: Parent-offspring conflict and sibling rivalry. American Naturalist 146:1-24.
Hahn, D. C., And J. S. Hatfield. 1995. Parasitism at the landscape scale: Cowbirds prefer forests. Conservation Biology 9:1415-1424.

Hahn, D. C., J. A. Sedgwick, I. S. Painter, and N. J. Casna. 1999. A spatial and genetic analysis of cowbird host selection. Pages 204-217 in Research and Management of the Brown-headed Cowbird in Western Landscapes (M. L. Morrison, L. S. Hall, S. K. Robinson, S. I. Rothstein, D. C. Hahn, and T. D. Rich, Eds.). Studies in Avian Biology, no. 18.

HАTCH, S. A. 1983. Nestling growth relationships of Brown-headed Cowbirds and Dickcissels. Wilson Bulletin 95:669-671.

Holen, Ø. H., G.-P. SÆtre, T. Slagsvold, and N. C. Stenseth. 2001. Parasites and supernormal manipulation. Proceedings of the Royal Society of London, Series B 268:2551-2558.

Jensen, W. E., AND J. F. Cully, JR. 2005. Geographic variation in Brown-headed Cowbird (Molothrus ater) parasitism on Dickcissels (Spiza americana) in Great Plains tallgrass prairie. Auk 122:648-660.

Kilner, R. M. 2003. How selfish is a cowbird nestling? Animal Behaviour 66:569-576.

KILNer, R. M. 2005. The evolution of virulence in brood parasites. Ornithological Science 4:55-64.

Kilner, R. M., J. R. Madden, and M. E. Hauber. 2004. Brood parasitic cowbird nestlings use host young to procure resources. Science 305:877-879.

Kilpatrick, A. M. 2002. Variation in growth of Brown-headed Cowbird (Molothrus ater) nestlings and energetic impacts on their host parents. Canadian Journal of Zoology 80:145-153.

Kosciuch, K. L., T. H. Parker, And B. K. Sandercock. 2006. Nest desertion by a cowbird host: An antiparasite behavior or a response to egg loss? Behavioral Ecology 17:917-924.

KosCiUCH, K. L., AND B. K. SANDERCOCK. 2008. Cowbird removals unexpectedly increase productivity of a brood parasite and the songbird host. Ecological Applications 18:537-548.

Kus, B., S. L. Hopp, R. R. Johnson, And B. T. Brown. 2010. Bell's Vireo (Vireo bellii). In The Birds of North America Online (A. Poole, Ed.). Cornell Lab of Ornithology, Ithaca, New York. [Online.] Available at bna.birds.cornell.edu.bnaproxy.birds. cornell.edu/bna/species/035.

Lichtenstein, G., And S. G. Sealy. 1998. Nestling competition, rather than supernormal stimulus, explains the success of Brownheaded Cowbird chicks in Yellow Warbler nests. Proceedings of the Royal Society London, Series B 265:249-254.

LOWTHER, P. E. 2011. Lists of victims and hosts of the parasitic cowbirds (Molothrus). [Online.] Field Museum of Natural History, Chicago, Illinois. Available at fm1.fieldmuseum.org/aa/Files/ lowther/CBList.pdf.

Martin, T. E., And G. R. Geupel. 1993. Nest-monitoring plots: Methods for locating nests and monitoring success. Journal of Field Ornithology 64:507-519.

Martinez, J. G., J. J. Soler, M. Soler, And T. Burke. 1998. Spatial patterns of egg laying and multiple parasitism in a brood parasite: A non-territorial system in the Great Spotted Cuckoo (Clamator glandarius). Oecologia 117:286-294.

Mclaren, C. M., B. E. Woolfenden, H. L. Gibbs, and S. G. SEALY. 2003. Genetic and temporal patterns of multiple parasitism by Brown-headed Cowbirds (Molothrus ater) on Song Sparrows (Melospiza melodia). Canadian Journal of Zoology 81:281-286. 
Motro, U. 1989. Should a parasite expose itself? (Some theoretical aspects of begging and vigilance behavior). Journal of Theoretical Biology 140:279-287.

Ortega, C. P. 1998. Cowbirds and Other Brood Parasites. University of Arizona Press, Tucson.

PARKer, T. H. 1999. Responses of Bell's Vireos to brood parasitism by the Brown-headed Cowbird in Kansas. Wilson Bulletin 111:499-504.

PAYNE, R. B. 1977. Clutch size, egg size, and the consequences of single vs. multiple parasitism in parasitic finches. Evolution 58:500-513.

Queller, D. C., AND K. F. Goodnight. 1989. Estimating relatedness using genetic markers. Evolution 43:258-275.

Raymond, M., And F. Rousset. 1995. GENEPOP (version 1.2): Population genetics software for exact tests and ecumenicism. Journal of Heredity 86:248-249.

RiVERS, J. W. 2007. Nest mate size, but not short-term need, influences begging behavior of a generalist brood parasite. Behavioral Ecology 18:222-230.

RiVERS, J. W. 2008. An investigation of factors influencing nestling begging behavior in a generalist brood parasite. Ph.D. dissertation, University of California, Santa Barbara.

Rivers, J. W., D. P. Althoff, P. S. Gipson, And J. S. Pontius. 2003. Evaluation of a reproductive index to estimate Dickcissel reproductive success. Journal of Wildlife Management 67:136-143.

Rivers, J. W., P. S. Gipson, D. P. Althoff, and J. S. Pontius. 2010a. Long-term community dynamics of small landbirds with and without exposure to extensive disturbance from military training activities. Environmental Management 45:203-216.

Rivers, J. W., W. E. Jensen, K. L. Kosciuch, and S. I. Rothstein. 2010b. Community-level patterns of host use by the Brownheaded Cowbird (Molothrus ater), a generalist brood parasite. Auk 127:263-273.

Rothstein, S. I. 1975. An experimental and teleonomic investigation of avian brood parasitism. Condor 77:250-271.

Rothstein, S. I. 1990. A model system for coevolution: Avian brood parasitism. Annual Review of Ecology and Systematics 21:481-508.
Rousset, F. 2008. Genepop'007: A complete re-implementation of the GENEPOP software for Windows and Linux. Molecular Ecology Resources 8:103-106.

Sauer, J. R., J. E. Hines, And J. Fallon. 2008. The North American Breeding Bird Survey, Results and Analysis 1966-2007. Version 5.15.2008. U.S. Geological Survey, Patuxent Wildlife Research Center, Laurel, Maryland.

SCHUETZ, J. G. 2005. Low survival of parasite chicks may result from their imperfect adaptation to hosts rather than expression of defenses against parasitism. Evolution 59:2017-2024.

ScotT, D. M. 1963. Changes in the reproductive activity of the Brown-headed Cowbird within the breeding season. Wilson Bulletin 75:123-129.

Strausberger, B. M. 1998. Temporal patterns of host availability, Brown-headed Cowbird brood parasitism, and parasite egg mass. Oecologia 116:267-274.

Strausberger, B. M., And M. V. Ashley. 1997. Community-wide patterns of parasitism of a host "generalist" brood-parasitic bird. Oecologia 112:254-262.

Strausberger, B. M., And M. V. Ashley. 2003. Breeding biology of brood parasitic Brown-headed Cowbirds (Molothrus ater) characterized by parent-offspring and sibling-group reconstruction. Auk 120:433-445.

Strausberger, B. M., And M. V. Ashley. 2005. Host use strategies of individual female Brown-headed Cowbirds Molothrus ater in a diverse avian community. Journal of Avian Biology 36:313-321.

TARR, C. L. 1995. Primers for amplification and determination of mitochondrial control-region sequences in oscine passerines. Molecular Ecology 4:527-530.

Zimmerman, J. L. 1983. Cowbird parasitism of Dickcissels in different habitats and at different nest densities. Wilson Bulletin 95:7-22.

Zimmerman, J. L. 1993. The Birds of Konza: The Avian Ecology of the Tallgrass Prairie. University Press of Kansas, Lawrence.

Associate Editor: J. C. Reboreda 